\title{
Identifying the Main Determinants of Part-Time Employment in EU Countries
}

\section{Rasa Miežienė, Sandra Krutulienė, Boguslavas Gruževskis ${ }^{1}$}

\begin{abstract}
The article analyses the prevalence of part-time employment in different EU countries with a focus on the factors affecting the rate of part-time employment across the EU. Based on the literature review, a distinction is made between three groups of factors that are relevant for the rate of part-time employment, in particular, cyclical factors, political and institutional factors, and structural factors. The article analyses how these factors influence part-time employment rates in EU countries. The linear regression analysis based on EU-28 macroeconomic data for the period of 2007-2018 has shown that all three groups of determinants (i.e. cyclical, political and institutional as well as structural factors) affect the rate of part-time employment in the EU-28. Part-time employment is a complex phenomenon which depends on a number of factors. However, the regression analysis has found that the following political and institutional as well as structural independent variables are also significant predictors of part-time employment rates in EU Member States (EU-28): average annual wages, the tax rate on low wage earners, expenditures on children and family benefits as a percentage of gross domestic product, trade union density, and the activity rate of people aged 15-24 and 55-64. Cyclical factors (the unemployment rate in Model (1) and real GDP per capita in Model (2)) have also been found to have a significant effect on part-time employment in EU-28 countries.
\end{abstract}

Keywords: part-time employment, part-time work, cyclical factors, political and institutional factors, structural factors

JEL Classification: J22, J81

Received: 2 June 2020 / Accepted: 19 April 2021 / Sent for Publication: 8 June 2021

\section{Introduction}

Globalisation and rapid technological change determine the need for more flexible work arrangements in the labour market which, in turn, lead to an increase in atypical forms of employment. Over the past decades, one of the significant changes in working conditions in EU countries was the growth of part-time employment. According to Eurostat, 31.2 million women and 9.5 million men aged 20-64 worked part-time in the EU in 2018. The

\footnotetext{
${ }^{1}$ Lithuanian Centre for Social Sciences, Institute of Sociology, Department of Labour Market Research, Vilnius, Lithuania. rasa.zabarauskaite@dsti.lt, sandra.krutuliene@dsti.lt, boguslavas.gruzevskis@dsti.lt

C 2021 by the authors; licensee Review of Economic Perspectives / Národohospodářský obzor, Masaryk University, Faculty of Economics and Administration, Brno, Czech Republic. This article is an open access article distributed under the terms and conditions of the Creative Commons Attribution 3.0 license, Atribution - Non Commercial - No Derivatives.
} 
share of people working part-time in the EU increased from $15 \%$ in 2002 to $19 \%$ in 2018 (Eurostat, 2019). Furthermore, recent studies have revealed a significant decrease in hours worked among EU workers due to the COVID-19 pandemic. According to Eurofound (2020), "most Member States experienced a drop in the index of total actual hours worked in the main job between the last quarter of 2019 and the first quarter of 2020. The highest decrease was observed in Italy (-9.7\%), followed by Slovakia (-8.7\%), Greece and Austria (both -7.9\%)" (Eurofound, 2020, p. 11).

In modern societies, part-time employment is an important tool for reconciling work and family responsibilities, developing employment among disadvantaged groups, and ensuring higher employment levels in cyclical economic periods unfavourable for the labour market (Miežienė \& Gruževskis, 2018). However, looking at Eurostat data, we can see large differences in part-time employment rates prevailing between EU countries. In 2019, the highest part-time employment rates were in the Netherlands (50.2\%), Austria (27.2\%), and Germany (27.2\%); countries with the lowest rates included Bulgaria (1.9\%), Hungary $(4.4 \%)$, and Slovakia (4.5\%). The question arises: Why do such differences prevail, and what are the main factors that determine the rate of part-time employment in EU countries.

Over the past few decades, the issue of part-time employment has received considerable attention from researchers. We can mention at least several studies that sought to determine the factors affecting the rate of part-time employment in different European countries. E.g. Buddelmeyer et al. (2008), based on Eurostat and OECD data from 1984-2001, investigated how the business cycle and structural factors influenced the development of part-time employment in EU-15 countries. Fialova (2017a), based on Eurostat and OECD data sample (1998-2013) from 28 European countries, analysed the differences in parttime employment in Eastern European and Western European countries. Bielenski et al. (2002) based their analysis of part-time employment factors on a micro approach - researchers conducted a representative population survey in EU-15 countries and Norway. Euwals \& Hogerbrugge (2004) investigated the factors of supply and demand for the growth of part-time employment using the Dutch Labour Force Survey data from 19912001 .

In addition to the mentioned studies, some researchers focused on one or several determinants of part-time employment, e.g. the impact of economic cycles on part-time employment was analysed by Kang et al. (2019), Borowczyk-Martins (2017), Fialova (2017b); the links between structural variables such as workforce or wage structure were analysed by Valletta et al. (2018), Miežienè \& Gruževskis (2018), Kretsos \& Livanos (2016); motivational factors influencing part-time employment were analysed by Pons et al. (2017), Larsson \& Bjork (2017), etc.

This study contributes to the literature on part-time employment by shedding more light on the factors determining the prevalence of part-time employment in EU countries. It is an attempt to identify the factors that contribute to the rate of part-time employment in EU-28 countries (i.e. combining both Eastern and Western countries). In the analysis, we use a large set of determinants identified by other authors (Fialova (2017a), Buddelmeyer et al. (2008), Hipp et al. (2015), etc.).

The aim of this paper is to identify the main factors affecting the rate of part-time employment in EU-28 countries. The paper seeks to examine how and to what extent differ- 
ent economic, labour market and demographic as well as institutional indicators may affect the rate of part-time employment in EU countries. The analysis is based on macroeconomic data in 28 European countries for the period of 2007-2018 provided by Eurostat, OECD, and other sources. In the paper, the concepts "part-time work" and "part-time employment" are used interchangeably.

The paper is organised as follows. In the first section, we review the literature on parttime employment with a view to identifying the main factors influencing the rate of parttime employment as well as highlighting the advantages and disadvantages of working part-time. In the second section, we present the research methodology employed in the study. The third section is devoted to the analysis of trends of part-time employment in EU-28 countries. In the fourth section, based on regression analysis, we identified the factors having the greatest impact on part-time employment.

\section{Theoretical background of part-time employment}

\subsection{Defining part-time employment}

Part-time employment differs from full-time employment in terms of the number of hours worked (Borowczyk-Martins, 2017). Part-time work is usually defined as regular wage employment in which the hours of work are less than "normal" (Thurman \& Trah, 1990; Kalleberg, 2000). According to the International Labour Organization (ILO) Part-Time Work Convention, 1994 (No. 175), "The term part-time worker means an employed person whose normal hours of work are less than those of comparable full-time workers". Some statistical agencies use a 35 hour cut-off (per week) when defining part-time workers (e.g. the US Bureau of Labor Statistics), others - 30 hours per week (e.g. OECD) (OECD, 2020; Borowczyk-Martins, 2017).

In our article, the Eurostat definition of part-time work is used. Eurostat uses individuals' self-reported part-time employment status, which means that the distinction between fulltime and part-time work is made on the basis of a spontaneous answer given by the respondent. According to Eurostat, "it is impossible to establish a more exact distinction between part-time and full-time work, due to variations in working hours between the Member States and branches of industry" (Eurostat, 2020). Thus, part-time employment indicates the percentage of part-time workers as compared to total employment, based on results from the European Labour Force Survey (EU LFS) (Cedefop, 2019).

\subsection{Factors affecting the rate of part-time employment}

The person's choice to work part-time is influenced by a variety of factors. Decisions on entering employment and on the hours worked can be determined by an individual situation, household characteristics, economic or other factors. According to Bielenski et al. (2002), employment rates and the duration of working time are mainly determined by the following six factors: (1) individual characteristics; (2) employment situation; (3) household situation; (4) economic situation; (5) regulation; (6) work organisation. E.g. a rigid work organisation system makes it difficult to realise individual working time preferences, or inadequate regulatory framework that offers little scope for choosing working time can reduce the incidence of part-time employment (Bielenski et al., 2002). This gives us an assumption that working time preferences can be determined by micro or macro level factors. It should be noted that a greater focus in this article is put on macro level factors 
since the analysis of micro level factors (e.g. the person's qualification, health status, individual career orientations, etc.) may require different research techniques (e.g. micro data analysis).

The research shows that when talking about the determinants of part-time employment, we should consider the factors from both supply and demand-side (Barbieri et al., 2019; Euwals \& Hogerbrugge, 2004; O’Dorchai et al., 2007). What concerns the supply side, according to O'Dorchai et al. (2007), some categories of persons would always prefer to work part-time rather than full-time (and vice versa). This might particularly be the case with regard to young workers (students), young parents, older workers, disabled people and others. According to Barbieri et al. (2019), part-time jobs provide opportunities for individuals who would not otherwise be able to participate in the labour market. E.g., many studies have shown that the growing female labour force participation over the last few decades was one of the principal determinants that increased the incidence of parttime employment in many European countries (Euwals \& Hogerbrugge, 2004; Barbieri et al., 2019; Booth \& van Ours, 2012). It relates to the fact that part-time employment is highly gendered and often seen as a means of achieving work-life balance. According to Fialova (2017a), there are two main drivers to work part-time for women, namely, motherhood and caring responsibilities. Booth \& van Ours (2012) conclude that without the existence of part-time jobs, female labour force participation would be substantially lower since women confronted with the choice between a full-time job and zero working hours would opt for the latter. Based on a sample of 3,509 observations for Dutchmen and 3,449 observations for Dutch women, the researchers concluded that part-time jobs were what most Dutch women preferred (Booth \& van Ours, 2012).

On the other hand, part-time employment might be a result of labour market related demand-side dynamics because, more generally, firms use part-time workers as a low-cost means of adjusting to variable and uncertain demand (Hirsch, 2004). Employers usually use part-time employment for three main reasons: "for recruitment and retention; for optimal staffing to provide operational flexibility; or, to reduce hourly labour costs by creating jobs that can be filled at lower hourly rates of pay" (Fagan et al., 2014, p. 41). From this perspective, part-time work is perceived as a marginalised, secondary form of employment, as it represents a source of cheaper and flexible labour to firms (Fialova, 2017a). From this point of view, part-time employment can be explained by the dual labour market theory, which asserts that economic forces encourage the division of the labour market into separate submarkets, distinguished by different labour market characteristics and behavioural rules. A primary submarket is characterised by high wages, steady employment, and high job security, while a secondary submarket entails less favourable working conditions, little job security, and high turnover rates (Reich et al., 1973).

A literature review has also shown that researchers distinguish three main groups of determinants of part-time employment. These are "cyclical factors" related to changes in labour demand (i.e. business cycles); "political and institutional factors" related to labour market institutions and policies; and "structural factors" related to demographic and/or industrial structure (Buddelmeyer et al., 2004; Valletta et al., 2018; Borowczyk-Martins, 2017).

Cyclical factors. Cyclical part-time employment is caused by economic downturns and upturns. According to Buddelmeyer et al. (2004), business cycles affect changes in the 
part-time employment rate in short to medium term. The rate of part-time employment usually increases during recessions as employers offer part-time employment as a way to adjust hours worked over the cycle. Such a situation is determined by the fact that some firms face lower demand and are forced to reduce their costs by dismissing their employees, or lowering their wages and/or hours worked (Buddelmeyer et al., 2004; BorowczykMartins, 2017). In this way, employers can use part-time work to reduce hours worked without incurring turnover costs, and employees, in turn, may be willing to accept parttime work in a downturn, when the value of their outside option declines (Valletta et al., 2018).

However, it should be noted that cyclical factors may affect part-time employment both cyclically and counter-cyclically as there are several channels of influence (Fialova, 2017b; Valletta et al., 2018; Warren, 2016). According to Warren (2016), over the business cycle, part-time employment and unemployment are countercyclical and display similar volatilities. Mukoyama et al. (2019) made a similar conclusion that the part-time employment rate exhibits a countercyclical pattern, particularly in deep recessions.

Furthermore, economic cycles can have a different effect on the development of part-time employment in different countries. According to Fialova (2017b), the economic cycle has a different effect on the part-time employment rate in Eastern and Western European countries. She concludes that, contrary to the West, the business cycle development exerts a significant negative effect on the part-time employment rate in Eastern Europe. When the economy operates below its potential, part-time employment tends to grow more than full-time employment (Fialova, 2017b).

Political and institutional factors. As shown by the literature review, political and institutional factors have a long-term effect on part-time employment and include such factors as regulations on part-time work, wage level, employment protection legislation, childcare system, unemployment benefit system, tax system, trade unions, family, child and unemployment benefits, the share of temporary jobs, and others (Fialova, 2017b; Walsh, 1997; Buddelmeyer et al., 2004a; Nicolaisen et al., 2019).

A number of different types of regulations may have direct or indirect effects on the rate of part-time work. For example, statutory regulations may have a direct effect on parttime employment when the development of this form of employment is subject to certain limitations (Miežienė \& Gruževskis, 2018). Wage regulation, social protection systems, and tax and benefit systems fall under a set of regulations that affect part-time employment indirectly through shifting the financial incentives for firms to offer part-time opportunities and also for employees to accept them (Buddelmeyer et al., 2004b).

High income tax, unless differentiated by the level of income, may reduce incentives for employees to work part-time, as a large part of the income goes for taxes (Miežienè \& Gruževskis, 2018). According to Buddelmeyer et al. (2004b), financial disincentive is reinforced when income tax is computed on the basis of couple's earnings rather than on individual's earnings, since in such a system, the second earner in a couple may face a relatively high effective marginal rate.

Similarly, family or child benefit and unemployment benefit systems (together with other benefits) may create an 'unemployment trap' through high net replacement rates and long 
benefit duration. This is especially the case because part-time positions are usually lower paid and cannot offset the effect of benefits (Buddelmeyer et al., 2008; Fialova 2017a).

The literature shows that part-time employment is less common in Eastern European as compared to Western European countries (Fialova 2017a; Vaalavuo, 2016; Eurofound, 2012b). In Central and Eastern European countries, part-time work remains a marginal phenomenon even among women, while Western countries have embraced it much more widely (Vaalavuo, 2016). Low wages in Central Eastern European countries could be one of the key reasons deterring employees from part-time work (Miežiene \& Gruževskis, 2018; Fagan et al., 2014).

Availability of childcare facilities can also encourage parents to work full-time, while limited access to childcare or expensive childcare services leaves working mothers with no alternative but part-time work (Yanez, 2015).

Trade union membership can also affect the rate of part-time employment. According to Eurofound (2012b), strong trade union representation may ensure that working time preferences are realised. Practice shows that in countries with a high trade union density, there tends to be a preference for a reduction in the volume of work (Eurofound, 2012b). On the other hand, some studies have shown that part-timers have a lower level of union membership. This relates to the fact that full-time workers are, traditionally, more likely to be union members than part-timers (Beck \& Fitzenberger, 2004). Part-time workers have less power and consequently have poorer working conditions and lower wages (O’Dorchai et al., 2007).

Other flexible forms of employment can also be related to part-time employment. According to Buddelmeyer et al. (2004a), in many countries the development in part-time jobs goes hand in hand with that of fixed-term contracts as complementary flexible staffing arrangements. A similar conclusion was made by Fialova (2017a), who found that part-time employment was positively related to the share of temporary jobs in Eastern European countries.

Structural factors. Another very important group of determinants of part-time employment is related to the demographic and industrial structure in a country. This group of determinants has a long-term effect on part-time employment and, among others, includes: the female labour force participation rate, the participation rate of young (aged 15-24) and older people, the share of employment in the service sector, the fertility rate, the size of the shadow economy, etc.

Part-time employment is often associated with female participation in the labour market. This relates to the fact that part-time work is often seen, both in politics and in scientific literature, as a key strategy to achieve a better work-life balance. As a policy issue, worklife balance seems to pertain almost exclusively to women, as it is most often women who carry the bulk of caring responsibilities, and it is less commonly suggested that men should achieve a better work-life balance through part-time work (Nicolaisen et al., 2019). According to Eurostat, in 2018, the average rate of part-time employment for women in EU countries was $31.3 \%$. For men, part-time levels were far lower in 2018, with an EU average of $8.7 \%$.

The share of young people or the schooling rate of the population aged 15-24 is also likely to positively influence the part-time employment rate. On the one hand, young people are 
mainly looking for part-time jobs that allow them to combine studies and work. On the other hand, some newly graduated students may be ready to accept part-time work in order to build up professional experience and avoid unemployment spells (Buddelmeyer et al., 2004a).

Furthermore, part-time work is a good tool to mobilise disadvantaged labour-market groups with lower participation rates, such as disabled or older workers (Fagan et al., 2014). According to Sargeant (2011), there is a direct relationship between working parttime and getting older in the UK, meaning that the proportion of older people working part-time is much higher as compared to younger employees.

Some studies have revealed that the share of employment in services and organisational flexibility in general can also contribute to the growth of part-time employment (Euwals \& Hogerbrugge, 2004; Buddelmeyer et al., 2004a). The growth of the service sector and the liberalisation of laws on opening hours of shops have led to greater demand for labour on non-standard working hours (Euwals \& Hogerbrugge, 2004). In general, workers in manufacturing tend to work longer hours than those in the service sector (Eurofound, 2012 b). This relates to the fact that employers in the service sector more often hire parttime workers in order to deal with regular and predictable peaks of demand ("rush hours") or to extend opening hours on evenings or weekends. Conversely, mass-production and capital-intensive industries rely far more on full-time workers (Buddelmeyer et al., 2004a).

The growing total fertility rate can also contribute to the growth of part-time employment as it creates an enhanced need for reconciling work and family responsibilities. This is especially the case when the child care system is insufficient (Gomes et al., 2012; Buddelmeyer et al., 2004a).

Some studies have also shown a positive effect of the shadow economy on the rate of part-time employment (Fialova, 2017a). This effect is more obvious for Eastern European countries, since informal employment is more prevalent in Central and Eastern European countries as compared to Western European countries (Kelmanson et al., 2019). In the case of part-time informal employment, there are practices when employment contracts are in place, but only a part of wages is formally reflected in accounting records (Krumplyte, 2010).

\subsection{Advantages and disadvantages of part-time work}

Part-time work has always been a controversial issue. On the one hand, part-time employment has been publicly praised as a tool for promoting market flexibility and reorganising working time, for family policy and for redistributing existing employment (thereby reducing unemployment) (Isusi \& Corral, 2004). It has made possible a continuing labour force attachment for some groups of people in periods of the life cycle when family demands are particularly pressing (Kahne, 1994). On the other hand, part-time employment is often associated with marginal employment (Fagan \& O’Reilly, 1998; Hipp et al., 2015) and precarious work (Thurman \& Trah, 1990).

From the demand point of view, part-time work can increase production flexibility, reduce pressures on doubly burdened family heads, and make possible an increase in worker productivity, thus helping to raise full-time earnings above poverty levels (Kahne, 1994). According to Tummers \& Woittiez (1991), part-time avoids the negative fatigue effect 
which causes marginal productivity to drop in case of long working hours or overtime. Kunn-Nelen (2011) make a similar conclusion - a larger part-time employment share leads to greater firm productivity which is basically due to allocation efficiencies. A negative aspect from the demand point of view is that part-time employment may increase overall labour costs for businesses due to the presence of fixed costs (e.g. recruitment, training, social security) (Eurofound, 2012b).

From the supply point of view, part-time work gives specific advantages to certain groups of workers. For women, young and older people, a part-time schedule offers the opportunity to stay in the labour market and combine work with home and caring activities, education, or leisure (Shagvaliyeva \& Yazdanifard, 2014; Yanez, 2015; Booth \& van Ours, 2012). The research has shown that employees working reduced hours achieve a better work-life balance (Shagvaliyeva \& Yazdanifard, 2014). Older people may prefer to work part-time because of health problems (Eurofound, 2012b). This type of part-time employment is predominantly voluntary and in most countries accounts for the largest fraction of part-time employment (Borowczyk-Martins, 2017).

Part-time has a positive effect on the employment rate as it increases female and older persons' participation in the labour force (Eurofound, 2012b; Sewdas et al., 2017; Euwals $\&$ Hogerbrugge, 2004). Some studies have shown (Sewdas et al., 2017) that having flexible working arrangements (working part-time was mentioned as the most important factor) is an important precondition for prolonging the work participation of older people. Older people place greater value on flexibility at work, adjustments, or part-time working hours to accommodate health needs or caring (Marvell \& Cox, 2017).

Despite the mentioned advantages, there are several negative aspects related to part-time employment. One of them is involuntary part-time employment that refers to individuals who work part-time because they cannot find a full-time job. Involuntary part-time work has a negative impact on both the individual and the economy as a whole. On an individual level, a full-time worker who takes on a part-time job, first of all, suffers a large reduction in earnings (Borowczyk-Martins, 2017). With fewer hours worked, part-time work differs from full-time work in terms of wages received. According to Eurostat, in 2016, full-time employees in the EU were paid on average for 38 hours per week and part-time employees were paid for 20 hours per week (Eurostat, 2019). From the macroeconomic perspective, involuntary part-time work can have similar effects as unemployment - it may reduce national output and overall economic performance (BorowczykMartins \& Lalé, 2016).

Furthermore, working part-time is likely to entail worse working conditions for employees and lower access to social security and fringe benefits compared to full-time work (Borowczyk-Martins, 2017). For this reason, part-time work is often associated with marginal employment (Fagan \& O’Reilly, 1998; Hipp et al., 2015) and precarious work (Thurman \& Trah, 1990). Quite often employers offer part-time jobs with poorer conditions to give their businesses numerical and financial flexibility. This type of part-time employment is characterised by working conditions and social protection of low quality and often a very low number of contracted hours (Nicolaisen et al., 2019). Studies have also shown that part-time workers more often have lower job status, poorer training and career opportunities, they perceive fewer job alternatives, experience less career goal progress, professional ability development, and promotion speed compared to those in full- 
time jobs (Osch \& Schaveling, 2020; Eurofound, 2012a). Moreover, some studies have shown that part-timers are less satisfied with their job than full-timers (Karatuna \& Basol, 2017; Miller \& Terborg, 1979).

Part-time employment is quite common among young people first entering the labour market. At first glance, this can be seen as a positive trend, assuming that part-time work is used as a stepping stone for young people to enter the labour market. Likewise, youth part-time employment is frequently associated with training opportunities. However, studies have shown that those young people who start their positions in part-time jobs spend quite a long time in them (Corrales-Herrero \& Rodriguez-Prado, 2016, Bruno et al., 2013).

It should be noted, however, that this article addresses involuntary part-time employment only in a fragmentary manner in order to better reflect the part-time employment situation in the different EU Member States, without more extensive analysis of the factors of involuntary part-time employment.

\section{Research methodology}

The aim of this study was to examine the factors affecting the rate of part-time employment among people aged 15-64 in EU-28 countries. On the basis of the literature review, three groups of factors relevant for the rate of part-time employment and their characteristic indicators were identified. The indicators were selected taking into account whether long-term data on the indicator are available for most of the countries covered by the analysis.

Cyclical factors are a group of factors that reflect fluctuations in economic cycles. The following indicators were analysed under this group:

1) Real gross domestic product (GDP) per capita (the indicator is measured in U.S. dollars at current prices and purchasing power parities (PPPs)). Source of data: OECD.Stat.

2) Unemployment rate (15-64) as a percentage of active population (\%) [lfsa_ergan]. Source of data: Eurostat.

Political and institutional factors encompass factors related to labour market institutions and policies. This group of factors has impact on the part-time employment rate in the long run (Buddelmeyer et al., 2004). It was much more difficult to distinguish indicators in this group in comparison with the indicators in the first or third group, since labour market institutions and policies are more reliant on legal regulation, which cannot be measured by certain indicators. The following indicators have been assigned to this group of factors for the purpose of analysis in the article:

1) Average annual wages (the indicator is measured in constant 2019 U.S. dollars and PPPs). Source of data: OECD.Stat.

2) Tax rate on low wage earners - low wage trap (\%) [earn_nt_lowwtrp]. Source of data: Eurostat. 
3) The percentage of children under 3 years of age (as a percentage of all children in the same age group) who are not in any sort of formal childcare ${ }^{2}(\%)$ [TPS00185]. Source of data: Eurostat.

4) The percentage of children aged between 3 years and the compulsory school age (as a percentage of all children in the same age group) who are not in any sort of formal childcare (\%) [TPS00185]. Source of data: Eurostat.

5) Expenditures on children and family benefits as a percentage of GDP (\%) [spr_exp_ffa]. Source of data: Eurostat.

6) Trade union density (administrative data) (\%). Source of data: OECD.Stat.

The factors of demographic and industrial structure (structural factors) include indicators that characterise both the demographic and labour market structure in EU countries. This group of factors includes the following indicators:

1) Total fertility rate [tps00199]. Source of data: Eurostat.

2) Active female population in the age group 15-64 as a percentage of total population (\%) [lfsi_emp_a]. Source of data: Eurostat.

3) Proportion of people aged 30-34 with tertiary education (ISCED level 5-8) (as a percentage of corresponding age population) (\%) [T2020_41]. Source of data: Eurostat.

4) Activity rate of people aged $15-24$ as a percentage of total population (\%) [TEPSR_WC160]. Source of data: Eurostat.

5) Activity rate of people aged 55-64 as a percentage of total population (\%) [TEPSR_WC160]. Source of data: Eurostat.

The annual data of part-time employment rates are taken from Eurostat for the period from 2007 to 2018 and include EU-28 countries (including the UK). Data on cyclical factors, structural factors, and most data on political and institutional factors are taken from Eurostat, except for data on average annual wages and data on trade union density (administrative data) which are obtained from the OECD.Stat database. It should be noted that most of the data used in our analysis were available for the period from 2007 to 2018 on the EU-28 Member States, but some data (e.g. the percentage of children who are not in any sort of formal childcare) are available for the later period. For some indicators, the OECD data are available not for all EU-28 Member States ${ }^{3}$.

\footnotetext{
${ }^{2}$ According to Eurostat, formal arrangements are considered to include four types of childcare and education: education at pre-school, education at compulsory school, childcare at centre-based services outside school hours (before/after) and childcare at day-care centre (https://ec.europa.eu/eurostat/databrowser/view/tps00185/default/table?lang=en).

${ }^{3}$ Data on average annual wages drawn from OECD do not include data from Bulgaria, Croatia, Cyprus, Malta, and Romania. Data on trade union density taken from OECD do not include data from Bulgaria, Croatia, Cyprus, Malta, Portugal, and Romania.
} 
In order to determine the cyclical, political and institutional, as well as structural determinants of part-time employment, we used the following aggregate model specification in the analysis:

$$
P T_{i t}=\alpha+\sum_{k=1}^{K} a_{k} X_{k i t}+\sum_{j=1}^{J} b_{j} X_{j i t}+\sum_{n=1}^{N} c_{n} X_{n i t}+\varepsilon_{i t}
$$

where:

$\alpha-$ the intercept,

$\mathrm{X}_{\mathrm{k}}-$ cyclical factors,

$\mathrm{X}_{\mathrm{j}}$ - political and institutional factors,

$X_{n}-$ structural factors.

In order to identify the determinants of part-time employment in the EU Member States, we used a research methodology employed by Buddelmeyer et al. (2008) and Fialova (2017a). As our panel data analysis was generally limited to the short time series $(T=12)$, the unit root test required for testing stationarity in data was not performed.

In our regression analysis, we used the part-time employment rate (15-64) (i.e. part-time employment as a percentage of the total employment, [lfsa_eppgan]) as a dependent variable. After performing the diagnostic tests (the groupwise heteroskedasticity was tested using a modified Wald test and serial correlation was tested using a Lagram-Multiplier test), some heteroskedasticity and first-order autocorrelation cases were detected. In order to solve the issue of groupwise heteroskedasticity and first-order serial correlation, Buddelmeyer et al. (2008) and Fialova (2017a) used a feasible generalised least-squares (FGLS) technique. We also used this method to estimate the equation in our analysis.

Statistical analysis was conducted using STATA, version 11. The results of the study are presented in section 4 .

\section{Trends of part-time employment in EU countries}

Prior to starting a statistical data analysis, it is appropriate to overview the trends of parttime employment in EU countries to get a full picture of the spread of part-time work in individual EU countries.

Looking at Eurostat data (Figure 1), we can see significant differences between EU countries in part-time employment rates. In 2019, the highest levels of part-time employment were observed in the Netherlands (50.2\%), Austria (27.2\%), Germany (27.2\%) and the lowest - in Bulgaria (1.9\%), Hungary (4.4\%), and Slovakia (4.5\%). As we can see, the part-time employment rate is considerably higher in Western European and Scandinavian countries with a higher level of economic development and is far lower in Southern European and, particularly, in Eastern European countries. 
Figure 1. Part-time employment rate and involuntary part-time employment rate in EU countries in 2019 (\%) (population aged 15-64)

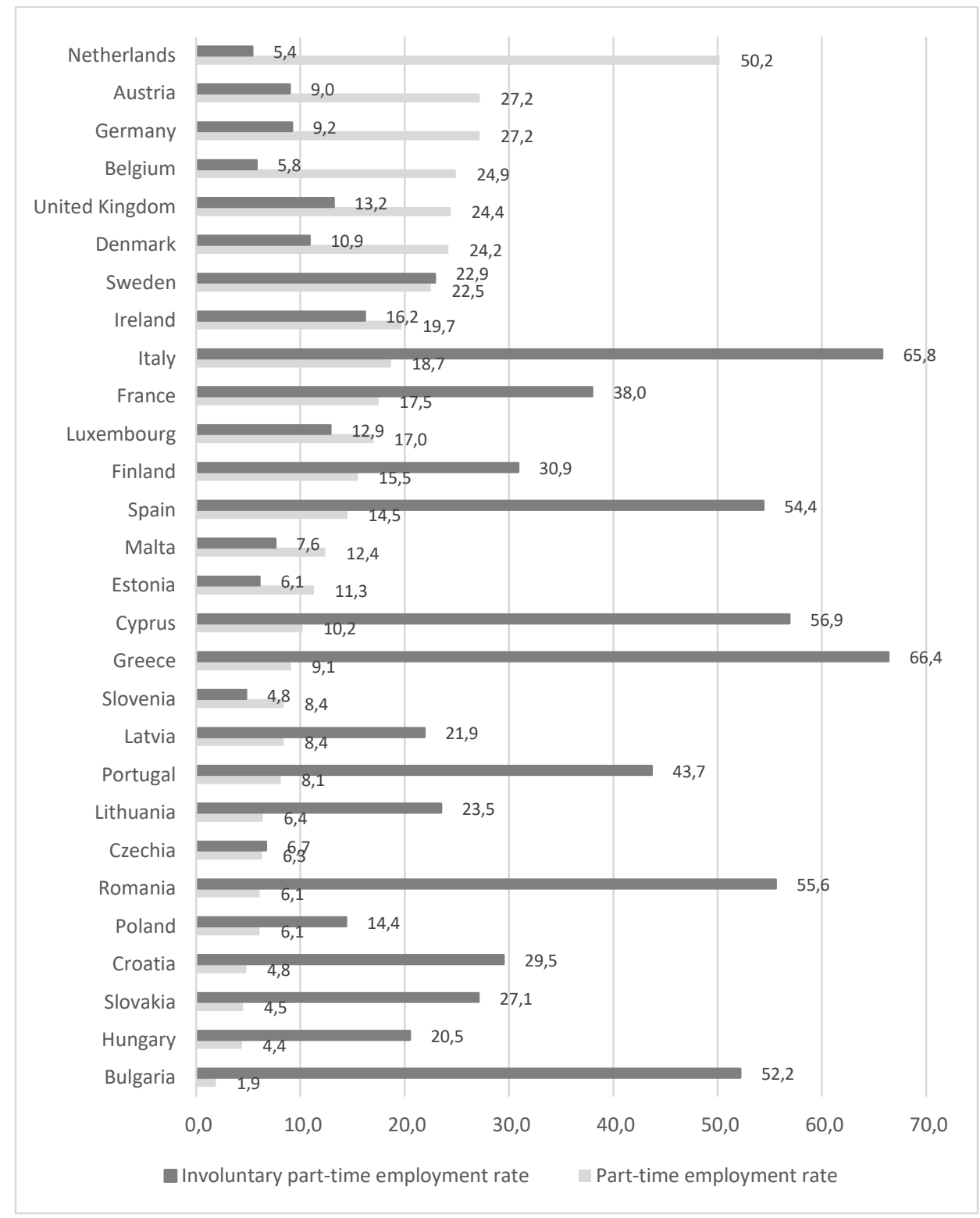

Source: Eurostat, [lfsa_eppga], [lfsa_eppgai].

As shown in Figure 1, the highest shares of involuntary part-time employment in 2019 were recorded in Greece and Italy $(66.4 \%$ and $65.8 \%$ of persons employed part-time, respectively) and the lowest were in Slovenia (4.8\%) and the Netherlands (5.4\%). Although, as already mentioned, part-time employment rates remain the lowest in Southern 
and Eastern European countries, involuntary part-time workers account for a particularly large share in these regions. It should be noted that the involuntary part-time employment rate is also high in some Scandinavian countries. For instance, about a third $(30.9 \%)$ of employees worked part-time involuntarily in Finland and about a fifth (22.9\%) in Sweden.

As for long-term trends, Eurostat data show that the share of part-time workers (including involuntary part-time workers) kept growing, although slowly, in EU countries over the last decade (Figure 2). The average rate of part-time employment (as a percentage of the total employment) increased from $17.4 \%$ in 2007 to $19.1 \%$ in 2019 in the EU-28.

Figure 2. Part-time employment rate and involuntary part-time employment rate in EU countries in 2007-2018 (\%) (population aged 15-64)

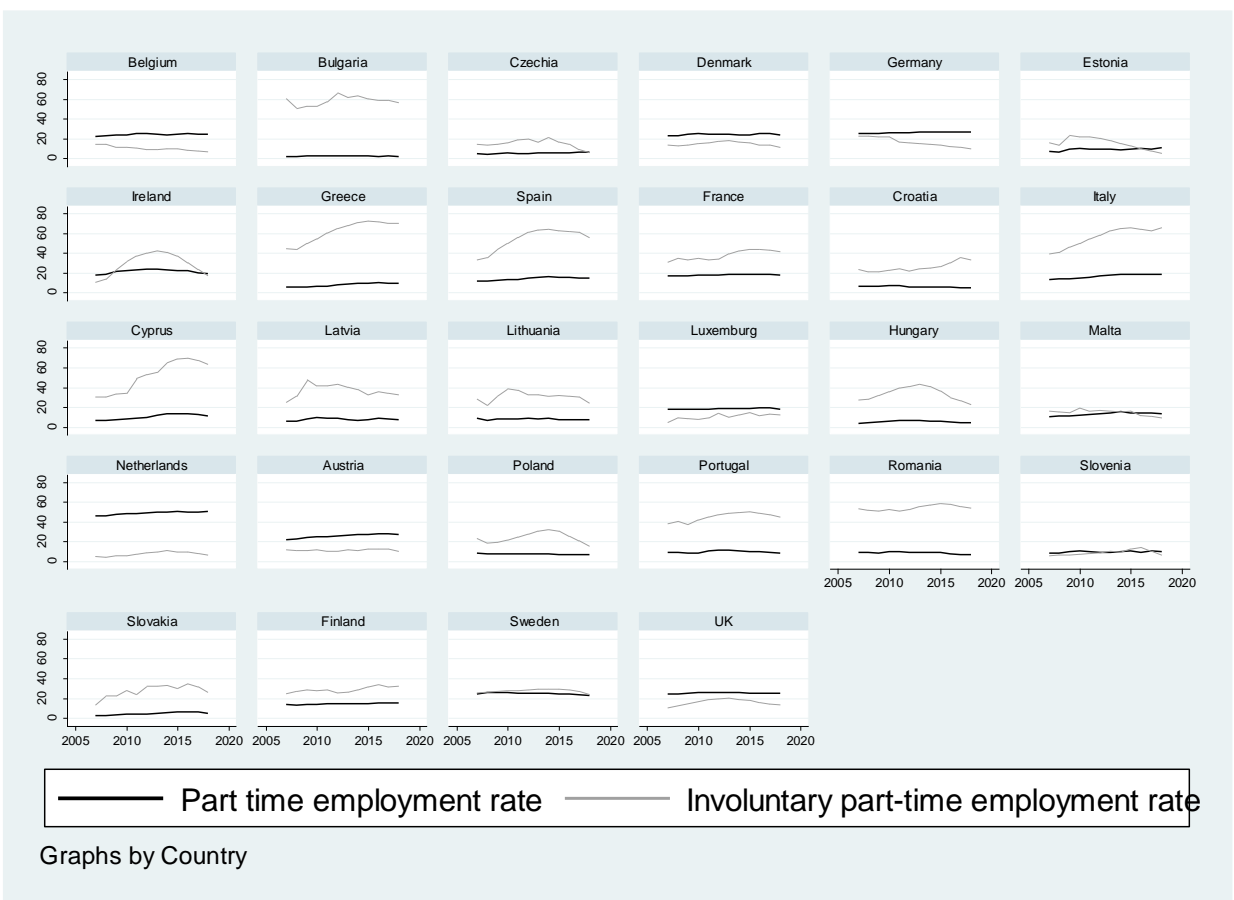

Source: Eurostat, [lfsa_eppga], [lfsa_eppgai].

The rate of involuntary part-time employment has also slightly grown in most EU countries over the last decade. According to Eurostat data, this indicator averaged $23.6 \%$ in the EU-28 in 2019, as compared to $22.4 \%$ in 2007 . It should be noted, however, that the highest mean value of this indicator $(29.3 \%$ ) was reached in 2013 . This may be due to the fact that many companies were unhurried to recruit staff on a full-time basis in the situation when the country's economy was recovering after the 2008-2009 crisis, and were to offer part-time employment instead. Thus, in summary, the relevance of part-time employment is increasing in many EU countries, and it is therefore important to study factors that influence the development of this form of employment. 


\section{Factors affecting part-time employment in EU-28 countries}

We employed the FGLS method to determine the factors of part-time employment in EU28 countries. The analysis results are presented in Table 1.

The analysis has shown that all three groups of determinants (i.e. cyclical, political and institutional as well as structural factors) influence the rate of part-time employment in EU-28 countries. We will discuss the factors that are statistically significant in more detail.

To avoid multicollinearity, we separated cyclical factors in Table 1. Real GDP per capita is analysed in Model (1) and the unemployment rate - in Model (2). We can see from Model (1) that the unemployment rate has a significant positive relationship with the rate of part-time employment - the increase in the unemployment rate leads to a higher share of part-time workers. These results comply with other research studies (e.g. Buddelmeyer et al., 2004) showing that "in an environment of falling economic activity and/or rising unemployment, workers may be more willing to consider part-time work as an alternative to their preferred labour supply choice of full-time employment" (Buddelmeyer et al., 2004a, p. 8). On the other hand, employers may also want to reduce hours worked during downturns. Drawing on Model (2), we can see that the real GDP per capita has a significant negative effect on part-time employment. With the increase in GDP per capita in PPPs, the rate of part-time employment tends to decrease.

With regard to political and institutional factors, the analysis has shown that average annual wages (AW), the tax rate on low wage earners, and trade union density have a significant positive effect on the rate of part-time employment in EU-28. Expenditures on children and family benefits as a percentage of GDP have a significant negative effect on the rate of part-time employment in EU-28 (Models (1) and (2)).

The effect of AW is quite clear - in countries where AW is low, it is simply not worthwhile for a person to work part-time as his or her earnings will not cover or only partially cover the additional costs that arise when the person starts to work (e.g., transport costs). It can also be one of the reasons, as concluded by Fialova (2017a), why people in Eastern Europe tend to work part-time less often compared to Western European people.

A significant positive relationship between part-time employment and tax rate on lowwage earners (low wage trap) seems somewhat surprising and is not so simple to explain. The low wage trap provides information on the financial consequences for an employed person when increasing his/her work effort and thus his/her wage. It measures which part $(\%)$ of the additional gross earnings is "taken away" through the combined effects of income taxes, social security contributions, and any withdrawal of benefits (Structural, 2002). This relationship may be related to the fact that, in many Western European countries with larger shares of part-time workers, the tax rate on low wages is higher as compared to Eastern European countries. E.g., according to Eurostat, in 2019, this indicator was $49 \%$ in the Netherlands, Germany $-45.1 \%$, Belgium $-60.4 \%$ (countries with the highest share of part-time employees), as compared to Bulgaria - $22.4 \%$, Hungary $33.5 \%$, Slovakia $-33.0 \%$ (countries with the lowest share of part-time employees).

The indicator of trade union density was found to be significantly positively related to the part-time employment rate as well. Although earlier studies found some evidence of a negative relationship between trade union density and part-time employment (Houseman, 2001), more recent studies show that many trade unions in the private and public sectors 
have redressed their historic reluctance to promote part-time working (Fagan et al., 2014). Currently, more and more attention in the agenda of trade unions is being paid to atypical forms of employment (including temporary work, part-time work, self-employment, and others) (Eurofound, 2010; Countouris and De Stefano, 2019). Thus, it is likely that employee involvement in trade unions provides greater security for part-time workers.

It should be noted that expenditures on children and family benefits (as a percentage of GDP) are significantly negatively related to part-time employment. Although the extent to which benefit systems affect individual labour market behaviour is difficult to predict, it can be assumed that greater support for families (in particular, financial support) can create an inactivity trap, as benefits paid to families are high relative to net income received from work. Thus, those parents who receive higher benefits from the state have lower financial incentives to work, especially if the work is on a part-time basis.

Our analysis has shown that the percentage of children between 3 years and compulsory school age who are not in any sort of formal childcare is not significantly related to the part-time employment rate in the EU-28.

In our analysis, only a few variables from the group of structural factors proved to be significantly relevant in explaining the rate of part-time employment.

It should be noted that, unlike in some other studies (e.g., Buddelmeyer et al., 2008; Fialova 2017a; Euwals \& Hogerbrugge, 2004), the relationship between the female activity rate and the part-time employment rate proved to be insignificant in our analysis. This may be due to the fact that the relationship between women's participation and part-time employment is not explicit. According to Barbieri et al. (2019), the combination of different macro-contextual dimensions determines the importance of part-time work regarding women's labour market participation. The researchers analysed data from the EULFS for 19 European countries for the period from 1992 to 2011 and found that the increasing availability of part-time work was associated with higher employment rates for women, but only in the Continental and Mediterranean clusters (Barbieri et al., 2019).

The proportion of people aged 30-34 with tertiary education was not found to be a significant predictor of part-time employment either. It is likely that people with tertiary education of this age tend to choose full-time rather than part-time employment. The participation rate of young people (aged 15-24) and older people (aged 55-64) was found to be significant predictors of part-time employment in EU-28 countries. The higher the activity rate in these groups, the higher the rate of part-time employment. Such a finding reveals that the structure of labour supply has a significant impact on the rate of part-time employment in the EU-28. According to Eurostat data, around 32.6\% of people aged 1524 and $22.1 \%$ of people aged 55-64 were in part-time employment (as a percentage of the total employment) in the EU-28 in 2019. The average EU-28 indicator for people aged 15-64 constituted $19.1 \%$ in 2019 . The higher share of part-timers in the group of very young and older people could be determined by several reasons. On the one hand, a large proportion of those working at a young age is forced to combine work with studies, while older people may want to work part-time for health-related reasons. On the other hand, the unemployment rate of young and older people is higher as compared to average indicators in many EU countries, thus, young and older people may be willing to accept parttime jobs as an alternative to full-time employment. 
It is of note that our research has some limitations: literature identifies considerably more factors of the part-time employment rate than are used in our analysis. Some groups of part-time employment factors cover a limited number of indicators characterising the part-time employment rate due to the lack of long-term data for all countries at issue, e.g. the group of political and institutional factors does not include indicators characterising the legal framework, as it is difficult to find comparable data between countries. In addition, it should be noted that clustering of the countries into separate groups according to various characteristics may have also influenced the research findings.

Table 1. Determinants of part-time employment rate in EU-28 Member States

\begin{tabular}{|c|c|c|c|}
\hline & Variables & $(1)$ & $(2)$ \\
\hline \multirow[t]{2}{*}{$\begin{array}{l}\text { Cyclical } \\
\text { factors }\end{array}$} & $\begin{array}{l}\text { Real gross domestic product (GDP) per capita in } \\
\text { PPPs (current prices) }\end{array}$ & & $-.0002^{* * * *}$ \\
\hline & Unemployment rate $(15-64)(\%)$ & $0.2925^{* * *}$ & \\
\hline \multirow{6}{*}{$\begin{array}{l}\text { Political and } \\
\text { institutional } \\
\text { factors }\end{array}$} & $\begin{array}{l}\text { Average annual wages in PPPs (constant prices in } \\
\text { 2019) }\end{array}$ & $0.0004^{* * *}$ & $0.0006^{* * *}$ \\
\hline & Tax rate on low wage earners - low wage trap (\%) & $0.1671^{* * *}$ & $0.0919^{* * * *}$ \\
\hline & $\begin{array}{l}\text { No formal childcare - children less than } 3 \text { years old } \\
\text { (as a } \% \text { of all children in the same age group) }\end{array}$ & 0.0170 & 0.0098 \\
\hline & $\begin{array}{l}\text { No formal childcare - children between } 3 \text { years and } \\
\text { compulsory school age (as a } \% \text { of all children in the } \\
\text { same age group) }\end{array}$ & -0.0078 & -0.0087 \\
\hline & $\begin{array}{l}\text { Expenditures on children and family benefits as } \\
\text { a } \% \text { of gross domestic product }\end{array}$ & $-1.682^{* * *}$ & $\begin{array}{c}- \\
- \\
1.2189^{* * *}\end{array}$ \\
\hline & Trade union density $(\%)$ & $0.0006^{* * *}$ & $0.0005^{* * *}$ \\
\hline \multirow{9}{*}{$\begin{array}{l}\text { Structural fac- } \\
\text { tors }\end{array}$} & Total fertility rate & 0.2553 & -2.0591 \\
\hline & $\begin{array}{l}\text { Active female population (aged 15-64) as a per- } \\
\text { centage of total population (\%) }\end{array}$ & -0.0740 & -0.0656 \\
\hline & $\begin{array}{l}\text { Proportion of people aged 30-34 with tertiary edu- } \\
\text { cation (ISCED level 5-8) as a percentage of corre- } \\
\text { sponding age population (\%) }\end{array}$ & 0.0084 & 0.0365 \\
\hline & $\begin{array}{l}\text { Activity rate of people aged } 15-24 \text { as a percentage } \\
\text { of total population }(\%)\end{array}$ & $0.2607^{* * * *}$ & $0.1883^{* * *}$ \\
\hline & $\begin{array}{l}\text { Activity rate of people aged 55-64 as a percentage } \\
\text { of total population (\%) }\end{array}$ & $0.1231^{* * * *}$ & $0.1337^{* * * *}$ \\
\hline & Constant & $22.348^{* * *}$ & $12.950^{* * * *}$ \\
\hline & Observations/groups/periods (max) & $214 / 23 / 11$ & $214 / 23 / 12$ \\
\hline & Common (AR1) coefficient for all panels & 0.6305 & 0.6354 \\
\hline & Wald (Chi2), p & $\begin{array}{c}2832.15 \\
0.000\end{array}$ & $\begin{array}{c}2601.13 \\
0.000\end{array}$ \\
\hline
\end{tabular}

Note: $* * *$ denotes coefficient significant at a level of 1 percent.

Dependent variable: The part-time employment rate (aged 15-64), in \%. Coefficients were obtained by feasible generalised least-squares estimation procedure allowing for heteroskedastic errors and common across-group first-order serial correlation.

Sources: Eurostat database, OECD.Stat database. 


\section{Conclusions}

Based on the literature review, all factors influencing the part-time employment rate can be divided into three main groups: (1) cyclical factors relating to changes in labour demand (i.e. business cycles), (2) political and institutional factors relating to labour market institutions and policies, and (3) structural factors characterising both the demographic and industrial structure of the country. The linear regression analysis conducted by the authors has shown that all three groups of determinants (i.e. cyclical, political and institutional, as well as structural factors) influence the rate of part-time employment in EU28 countries.

The final results of the analysis have revealed that cyclical factors have a significant effect on the rate of part-time employment. The analysis of cyclical factors with the GDP parameter has shown that the rate of part-time employment tends to decrease with the increase in GDP per capita. The analysis of cyclical factors with the unemployment rate has demonstrated a positive relationship between this indicator and part-time employment the increase in the unemployment rate leads to a higher share of part-time workers.

With regard to political and institutional factors, the analysis has shown that average annual wages, the tax rate on low wage earners and trade union density have a positive effect on the rate of part-time employment in the EU-28. Expenditures on children and family benefits as a percentage of GDP have a negative effect on the rate of part-time employment in the EU-28 Member States.

The regression analysis has shown that the structure of labour supply have a significant impact on the rate of part-time employment in EU-28 countries. The activity rates of young people (aged 15-24) and older people (aged 55-64) have been found to be significant predictors of part-time employment in EU-28 countries. The higher the activity rate in these groups, the higher the rate of part-time employment. It should be noted that unlike in some other studies (e.g., Buddelmeyer et al., 2008; Fialova 2017a; Euwals \& Hogerbrugge, 2004)), the relationship between the female participation rate and the part-time employment rate proved to be insignificant in our analysis.

The analysis has also set a framework for further research. Due to the limited scope of the present research, it was not possible to distinguish between voluntary and involuntary part-time employment when analysing the determinants of part-time employment in the regression analysis. It would be reasonable to determine the factors of involuntary parttime employment in order to examine whether these two types of part-time employment derive from different reasons. This is especially important, knowing that involuntary parttime employment, as well as other forms of precarious employment, tend to rise in the face of the COVID-19 pandemic (Eurofound, 2020). It is also of note that common national-level indicators alone are insufficient for accurate assessment of the transition of part-time employees between unemployment and full-time or other forms of employment (e.g. fixed-term employment); this type of analysis requires the use of micro data.

Disclosure statement: No potential conflict of interest was reported by the authors. 


\section{References}

BARBIERI P., CUTULI G., GUETTO R., SCHERER S. (2019). Part-time employment as a way to increase women's employment: (Where) does it work? International Journal of Comparative Sociology, 60(4), 249-268. https://doi.org/10.1177/0020715219849463.

BECK M., FITZENBERGER B. (2004). Changes in Union Membership over Time: a Panel Analysis for West Germany. Available at SSRN: https://ssrn.com/abstract $=591403$.

BIELENSKI H., BOSCH G., WAGNER A. (2002). Working time preferences in sixteen European countries, European Foundation for the Improvement of Living and Working Conditions, Dublin.

BOOTH A. L., VAN OURS J. C. (2012). Part-time jobs: what women want? Journal of Population Economics 26, 263-283. https://doi.org/10.1007/s00148-012-0417-9.

BOROWCZYK-MARTINS D. (2017). Why does part-time employment increase in recessions? IZA World of Labor, p. 397.

BOROWCZYK-MARTINS D., LALÉ E. (2016). How Bad Is Involuntary Part-time Work? IZA DP No. 9775. Institute for the Study of Labor.

BRUNO G.S.F., CAROLEO F.E., DESSY O. (2013). Stepping stones versus dead end jobs: exits from temporary contracts in Italy after the 2003 reform. Rivista Internazionale di Scienze Sociali, 121 (1), 31-62.

BUDDELMEYER H., MOURRE G., WARD M. (2004a). The Determinants of PartTime Work in EU Countries: Empirical Investigations with Macro-Panel Data. IZA DP No. 1361, Institute for the Study of Labor.

BUDDELMEYER H., MOURRE G., WARD M. (2004b). Recent Developments in PartTime Working EU-15 Countries: Trends and Policy. IZA DP No. 1415.

BUDDELMEYER H., MOURRE G., WARD M. (2008). Why do Europeans work parttime? A cross-country panel analysis. Working paper series No 872. European Central Bank. Available at https://core.ac.uk/download/pdf/6956525.pdf.

CEDEFOP (2019). Skills panorama. Available at https://skillspanorama.cedefop.europa.eu/en/indicators/involuntary-part-time-employment [accessed on 20 April 2020].

CORRALES-HERRERO H., RODRIGUEZ-PRADO B. (2016). The role of part-time employment among young people with a non-university education in Spain. Journal of Education and Work, 29, 167-198.

COUNTOURIS N., de STEFANO V. (2019). New trade union strategies for new forms of employment. ETUC. Brussels.

EDWARDS J. (2019). Unemployment is low only because 'involuntary' part-time work is high. Available at https://www.businessinsider.com/unemployment-vs-involuntarypart-time-work-underemployment-2019-1 [accessed on 24 April 2020].

EUROFOUND (2010). Trade union strategies to recruit new groups of workers. Dublin: European Foundation for the Improvement of Living and Working Conditions. Available 
at: https://www.eurofound.europa.eu/sr/publications/report/2010/trade-union-strategiesto-recruit-new-groups-of-workers.

EUROFOUND (2012a). Working time in the EU. Foundation Findings. European Foundation for the Improvement of Living and Working Conditions. DOI: 10.2806/30961.

EUROFOUND (2012b). Part-time Work in Europe - European Company Survey 2009. Dublin: European Foundation for the Improvement of Living and Working Conditions.

EUROFOUND (2020). Living, working and COVID-19, COVID-19 series, Publications Office of the European Union, Luxembourg.

EUROSTAT (2020). Persons employed part-time - total. Available at https://ec.europa.eu/eurostat/databrowser/view/tps00159/default/table?lang=en [accessed on 27 March 2020].

EUWALS R., HOGERBRUGGE M. (2004). Explaining the Growth of Part-Time Employment: Factors of Supply and Demand. IZA DP No. 1124. Institute for the Study of Labor.

FAGAN C., NORMAN H., SMITH M., GONZÁLEZ MENÉNDEZ M. C. (2014). In search of good quality part-time employment. Conditions of Work and employment series, 43. International Labour Organization.

FIALOVÁ K. (2017a). Why don't Eastern Europeans work part-time? Ekonomický časopis 65 (2), 125-142.

FIALOVÁ K. (2017b). Part-time employment and business cycle in Central and Eastern Europe. Review of Economic Perspectives-Národohospodářský Obzor, 17 (2), 179-203.

GOMES C. S., de OLIVEIRA I. T., PINTO M. L. R., CABRITA M. (2012). Fertility, Full-time and Part-time Female Employment in Europe. CIES e-Working Paper No $125 / 2012$.

HIPP L., BERNHARDT J., ALLMENDINGER J. (2015). Institutions and the prevalence of nonstandard employment. Socio-Economic Review, 13 (2), 351-377, doi: 10.1093/SER/MWV002.

HIRSCH B. T. (2004). Why do part-time workers earn less? The role of worker and job skills. Available at https://www.econstor.eu/bitstream/10419/20525/1/dp1261.pdf [accessed on 26 August 2020].

HOUSEMAN S. (2001). Why Employers use Flexible Staffing arrangements: Evidence from an establishment Survey, Industrial and Labor Relations Review, 55(1), 149-169.

ILO (1994). C175 - Part-Time Work Convention, No. 175.

ISUSI I., CORRAL A. (2004). Part-time work in Europe. European Foundations for the Improvement of Living and Working Conditions.

KAHNE H. (1994). Part-time work: A Reassessment for a changing economy. Social Service Review 68 (3), 417-436.

KALLEBERG A. L. (2000). Nonstandard employment relations: Part-time, temporary and contract work. Annual Review of Sociology, 26, 341-365. 
KANG H., PARK J., SUH H. (2019). Business Cycle, Great Recession and Part-time Jobs. Inha University IBER Working Paper Series, 2018-1.

KARATUNA I., BASOL, O. (2017). Job satisfaction of part-time vs. full-time workers in Turkey: The effect of income and work status satisfaction. International Journal of Value Chain Management 8(58), 58-72.

KELMANSON B., KIRABAEVA K., MEDINA L., MIRCHEVA B., WEISS J. (2019) Explaining the shadow economy in Europe: Size, causes and policy options. IMF Working Papers.

KRETSOS L., LIVANOS I. (2017). The extent and determinants of precarious employment in Europe. International Journal of Manpower, 37 (1), 25-43.

KRUMPLYTÉ J. (2010). Analysis of undeclared work: The Lithuanian case. The Proceedings of the 6th International Scientific Conference, May 13-14, 2010, Vilnius, Lithuania. Business and Management 2010, 650-657.

KUNN-NELEN A., GRIP A., FOUARGE, D. (2011). Is part-time employment beneficial for firm productivity? IZA DP No. 5423.

LARSSON J., BJORK S. (2017). Swedish fathers choosing part-time work. Community, Work \& Family, 20 (2), 142-161.

MARVELL R., COX A. (2017). What do older workers value about work and why? Institute for Employment Studies. Centre for Ageing Better.

MEDINA L., SCHNEIDER F. (2018). Shadow Economies Around the World: What Did We Learn Over the Last 20 Years? IMF Working Paper WP/18/17. Available at: file:///C:/Users/Rasa/AppData/Local/Temp/wp1817.pdf.

MIEŽIENĖ R, GRUŽEVSKIS, B. (2018). Determinants of part-time employment: Lithuanian experiences in the context of other EU countries. Latvijas Zinatnu Akademijas Vestis, 72 (2), 44-55.

MILLER H. E., TERBORG J. R. (1979). Job attitudes of part-time and full-time employees. Journal of Applied Psychology 64 (4), 380-386.

MUKOYAMA T., SHINTANI M., TERAMOTO K. (2019). Cyclical part-time employment in an estimated new Keynesian model with search frictions. CIRJE F-Series.

NICOLAISEN H., KAVLI H. C., JENSEN R. S. (2019). Dualisation of Part-time Work. The Development of Labour Market Insiders and Outsiders. Policy Press.

O’DORCHAI S., PLASMAN R., RYCX F. (2007). The part-time wage penalty in European countries: How large is it for men? IZA DP No. 2591. Available at http://ftp.iza.org/dp2591.pdf [accessed on 25 August 2020].

O’REILLY J., FAGAN C. (1998) (Eds.). Part-time prospects: an international comparison of part-time work in Europe, North America and the Pacific Rim. London: Routledge.

OECD (2020). Part-time employment rate” (indicator), Available at https://doi.org/10.1787/f2ad596c-en [accessed on 20 April 2020]. 
OSCH Y. VAN, SCHAVELING J. (2020). The effects of part-time employment and gender on organizational career growth. Journal of Career Development 47 (3), 328-343. https://doi.org/10.1177/0894845317728359.

PONS P. E., BURNETT D., WILLIAMS M. R, PAREDES T. M. (2017). Why do they do it? A case study of factors influencing part-time faculty to seek employment at a community college“. Community College Enterprise, 23(1), 43-59.

REICH M., GORDON D., EDWARDS R. (1973). Dual Labor Markets: A Theory of Labor Market Segmentation. American Economic Review, 63, 359-65.

SARGEANT M. (2011). Age Discrimination. Ageism in Employment and Service Provision. Ashgate Publishing Company.

SEWDAS R., de WIND A., van der ZWAAN L., van der BORG W. E., STEENBEEK R., van der BEEK A. J., BOOT C. (2017). Why older workers work beyond the retirement age: a qualitative study. BMC public health, 17(1). https://doi.org/10.1186/s12889-0174675-z.

SHAGVALIYEVA S., YAZDANIFARD R. (2014). Impact of Flexible Working Hours on Work-Life Balance. American Journal of Industrial and Business Management, 4, 2023.

STRUCTURAL INDICATOR "LOW WAGE TRAP" (2002). A briefing note with illustrative calculations for the Netherlands. Available at: https://ec.europa.eu/eurostat/cache/metadata/Annexes/earn_net_esms_an4.pdf.

THURMAN J. E., TRAH G. (1990). Part-time work in international perspective. International Labour Review, 129, 23-40.

TUMMERS M. P., WOITTIEZ I. (1991). A simultaneous wage and labor supply model with hours restrictions. Journal of Human Resources 26(3), 393-423.

VAALAVUO M. (2016) Part-time work: A divided Europe. European Commission.

VALLETTA R. G., BENGALI L., VAN DER LIST C. (2018). Cyclical and Market Determinants of Involuntary Part-Time Employment. Federal Reserve Bank of San Francisco Working Paper 2015-19. Available at https://doi.org/10.24148/wp2015-19 [accessed on 19 February 2020].

WALSH T. (1997). Part-time Employment and Labour Market Policies. In: C. Ungerson M. Kember (eds) Women and Social Policy. Women in Society (A Feminist List). Palgrave, London.

WARREN F. L. (2016). Part-time employment and firm-level labor demand over the business cycle. Center for Economic Studies.

YANEZ N. M. (2015). The flexible Nature of Part-Time and the Reconciliation of Work and Family Life, In: L. M Mendez., L. Serrani (eds.) Work-life Balance and the Economic Crisis: Some Insights from the Perspective of Comparative Law (Volume I: The Spanish Scenario). Cambridge Scholars Publishing. 